Original Research Paper

\title{
Peculiarities of the Structure of Male Reproductive System in Trematode Parastrigea Robusta (Trematoda: Strigeidae)
}

\author{
${ }^{1}$ Rimma Meyramovna Ualiyeva, ${ }^{1}$ Kanat Kombarovich Akhmetov, \\ ${ }^{1}$ Indira Bulatovna Altayeva and ${ }^{2}$ Alexey Vasilyevich Surov \\ ${ }^{1}$ S. Toraighyrov Pavlodar State University, 64, Lomov Street, Pavlodar, 140000, Kazakhstan \\ ${ }^{2}$ A.N. Severtsov Institute of Ecology and Evolution, 33, Leninsky Prospekt, Moscow, 119071, Russia
}

Article history

Received: 24-02-2017

Revised: $18-03-2017$

Accepted: 10-06-2017

Corresponding Author:

Rimma Meyramovna Ualiyeva,

S. Toraighyrov Pavlodar State

University,

Email: ualieva_rimma@mail.ru

\begin{abstract}
It is well known that class Trematoda includes solely parasitic forms of flatworms. Therefore, they have developed diverse morphological and functional adaptations to the parasitic way of life. One of them is enormous fecundity, which allows quick and widespread settlement and finding hosts. Therefore, studying the reproduction apparatus of helminthes is the central problem of Parasitology. Studying functional morphology of the reproductive system of trematodes in general and its separate parts is of particular interest in addressing such a theoretically and practically important problem as direct regulation of endoparasites' fertility. This article presents thoruoug information about functional morphology of male reproduction apparatus in the Parastrigea robusta trematode, which is a parasite in the digestive system of common pochard (Nyroca ferina), which has not previously been studied and described in detail. As a result, the obtained knowledge about peculiarities of the structure of male reproductive system in trematode Parastrigea robusta will add substantially to the knowledge about particularities of the structure of male reproductive system of trematodes of Strigeidae family and endoparasites' fecundity in general.
\end{abstract}

Keywords: Helminthes, Trematodes, Male Reproductive System, Testes, Vasa Efferentia, Vasa Deferens, Seminal Vesicle, Ejaculatory Duct

\section{Introduction}

Parasitism is a widespread form of organisms' existence in the biosphere. This is because parasitic organisms have a huge variety of adaptations that ensure their existence both in the host organism and in the external environment (Terentieva and Kostevich, 2009; Zhavoronkova and Novak, 2015). The main of them are the adaptations that considerably increase reproductive activity of the parasites. In case of any degree of reduction of certain organs and systems in helminthes, the reproductive system in all cases invariably reaches high level of development, complexity and specialization. High reproductive potential of helminthes compensates for their high level of elimination at various stages of existence. Despite the fact that micromorphological features of the reproductive system in trematodes have been studied since the beginning of the twentieth century, detailed descriptions have been made only for several species of the 15,000 known (Kurochkin, 1990). Order Strigeida is represented by highest trematodes that have differentiated body, thereby attracting interest in studying them. Literature contains data about the structure of the anterior part of the body, the Brandes organ and pseudobothriums of maritas. The structure of their rear, or genital, segment has been studied in a fragmentary manner. The male reproductive system of trematodes Parastrigea robust a has been poorly studied, so the main goal of this work is a detailed study of the functional morphology of structural elements of the male reproductive system in $P$. robusta trematodes. This paper describes the micro-morphology of the testes, ducts and distal segments of $P$. robusta male reproductive system.

\section{Material and Methods of Research}

The object of study is the Parastrigea robusta trematode (Vojtek, 1972) that belongs to Strigeida order of Strigeidae family of the digestive system (intestines) of common pochard (Aythya ferina).

For the purpose of histological study, the material has been fixed in Buen liquid, which is used for fixation of whole mounts and pieces of tissues. 
The Buen liquid is represented by the following composition (Kiseli, 1962):

- $\quad$ Picric acid (saturated solution) $-150 \mathrm{~mL}$

- Formalin ( $40 \%$ formaldehyde solution) $-50 \mathrm{~mL}$

- Glacial acetic acid $-10 \mathrm{~mL}$

For the purpose of light-optical microscopy of ready microslides, the fixed helminthological material (trematodes) has passed several stages. The research material processing started with washing trematodes in $70 \%$ alcohol during the 1 st day. Trematodes were placed in special baskets with spacers for the biopsy material. The work was performed with the help of a hystoprocessor for tissue Medide TPC-15, where the material undergone through stages of tissue dehydration and paraffin impregnation according to program Standard 1 (Table 1).

As a result, the material was completely dehydrated and paraffin-impregnated.

Sections 5-7 microns thick were obtained with the use of a microtome, after pre-filling material in paraffin blocks. The slides fixed on glass were stained with hematoxylineosin using the method of Erlich (Kiseli, 1962).

Ready whole mounts were examined with a Keyence Bz-9000 light microscope, followed by photography of the slides at various magnification.

\section{The Results of the Study}

\section{The Overall Layout of the Structure}

The Parastrigea robusta trematode is characterized by availability of paired testes. They are rounded, compact, have large blades and are arranged one behind another (Fig. 1a-c). Two thin vas aefferentia go from the testes (Fig. 1c). Closer to the middle of the body, they merge into a short common duct, vas a deferens, which is directed towards the genital atrium and expands into a large elongated seminal vesicle (Fig. 1c). The distal end of the seminal vesicle is separated from the ejaculatory duct by a constriction. The distal ejaculatory duct is continued by a narrow duct that runs into the genital atrium (Fig. 1a-c). The area of the atrium is slightly separated. The genital cone is large and ovalary. The genital hole is terminal (Fig. 1a-c). The prostate gland is represented by unicellular glands penetrating the distal section of the ejaculatory duct (Fig. 1).

\section{Micromorphology of the Testes}

The testes have large blades and rounded shape; the testes diameter is $306 \mu \mathrm{m}$. The walls of the testes are thin membranes formed by fine connective tissue fibers; they are stained pink by hematoxylin-eosin (Fig. 2).

The entire inner surface of the testes, adhering directly to the walls, is covered by a continuous layer of the reproduction zone, which consists of primordial germ cells and spermatogonia (Fig. 2). The primordial germ cells are rounded, or slightly deformed, due to large clusters of cells and mutual pressure on each other. Their size ranges between 4.3 to 5.7 micrometers. The nuclei of these cells have oval or round shape, without the nucleolus, with distinct granules of chromatin of circular shape, are almost uniformly and rather loosely spaced around the core. The size of the nuclei ranges between 1.6 and $2.5 \mu \mathrm{m}$. Immediately before division, cells have the maximum size and the chromatin in the nucleus looks denser.

The primordial germ cells undergo a series of mitotic divisions, resulting in formation of type Ad, type Ap and type B spermatogonia, which are almost no different from the primordial germ cells. The structure of nuclei and occurrence of chromatin remain the same, which proves the slight morphological differences between spermatogonia and the primordial germ cells. Type Ad Spermatogonia have elongated shape, especially apical ends, from which cytoplasmic bridges go out. The size of these cells is approximately equal to 4.6 to $6.0 \mu \mathrm{m}$. Type Ap spermatogonia are the largest size of gonial forms-5.3 to $6.4 \mu \mathrm{m}$ and the diameter of the clone reaches $17.1 \mu \mathrm{m}$. Type $\mathrm{B}$ spermatogonia are less than type Ap spermatogonia- 4.8 to $5.9 \mu \mathrm{m}$ and the size of the clone are also reduced, as compared to the clones of type Ap Spermatogonia - 13.3 to $15.1 \mu \mathrm{m}$.

The resulting type B Spermatogonia enter the growth stage and become spermatocytes of I order, the dimensions of which reach 5.8 to $7.1 \mu \mathrm{m}$ and the diameter of the clone is 18.4 to $21.2 \mu \mathrm{m}$, whereby the size of the citophore also increases. After the first meiotic division, spermatocytes of the 1st order give start to 16 secondary spermatocytes, which, in thei turn, after second meiotic division, form 32 spermatids which corresponds to the data of Tacahiro et al. (1977) for Euritrema pancreaticum. The size of clones is reduced down to 17.1 to $18.6 \mu \mathrm{m}$ for secondary spermatocytes and 11.4-12.3 $\mu \mathrm{m}$ for spermatids, but the size of citophore increases; for these preparations, spermatocytes of $\mathrm{N}$-th order fine and spermatids have quite clearly identified cell boundaries.

Male germ cells of Parastrigea robusta have welldefined long tails (Fig. 2).

Formed male germ cells are removed from the gonads along the ducts in the male reproductive system towards the copulatory organ.

\section{Ducts and Distal Sections of the Male Reproductive System}

The proximal part of the excretory ducts of the male reproductive system of trematodes is, as a rule, presented by ductuli efferentes, extending from each testis and joining them with an unpaired vasa deferens (Fig. 3). Ductuli efferentes extend from the testes, which become the common vasa deferens. 
Table 1. Stages of tissues dehydration and paraffin impregnation in Medide TPC-15 hystoprocessor

\begin{tabular}{lll}
\hline No. & Name of reactant & Exposure (min) \\
\hline 1 & Alcohol 70 & 60 \\
2 & Alcohol 70 & 30 \\
3 & Alcohol 70 & 30 \\
4 & Alcohol 96 & 45 \\
5 & Alcohol 96 & 45 \\
6 & Alcohol 100 & 30 \\
7 & Alcohol $100^{\circ}$ & 30 \\
8 & Xylene & 20 \\
9 & Xylene & 20 \\
10 & Paraffin $60^{\circ}$ & 15 \\
11 & Paraffin $60^{\circ}$ & 15 \\
\hline
\end{tabular}

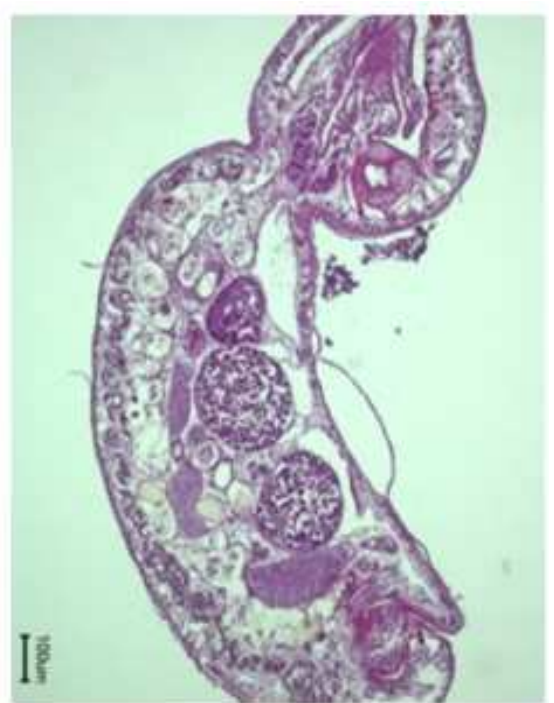

(a)

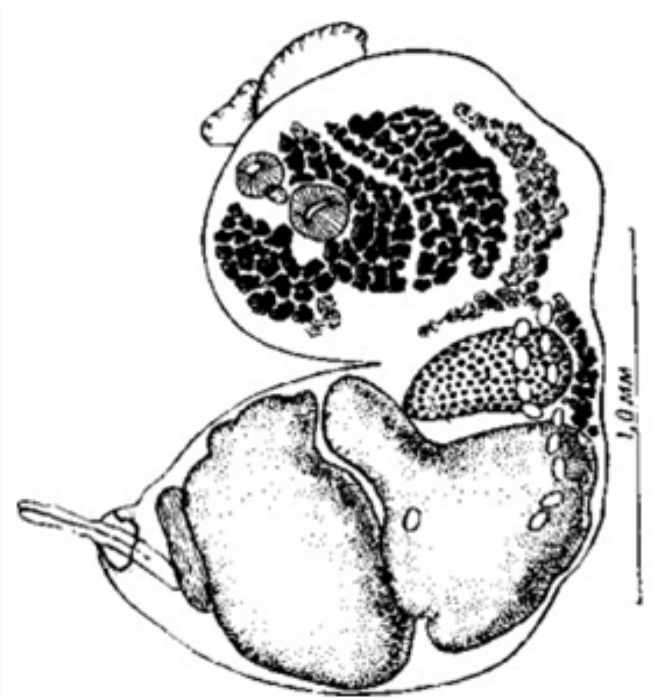

(b)

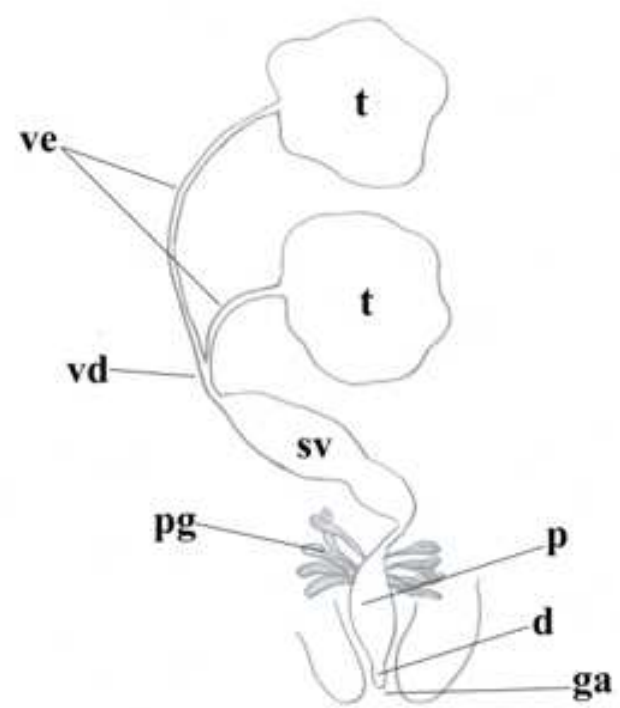

(c)

Fig. 1. General structural plan of the male reproductive system in Parastrigea robusta; (a) General view of Parastrigea robusta, (b) General view of Parastrigea robusta, (c) The diagram of the male reproductive system in Parastrigea robusta; t-testes; ve-vasa efferentia; vd-vasa deferens; sv-seminal vesicle; p-proximal part of the ejaculatory duct; (d) Distal part of the ejaculatory duct; pg- prostate gland; ga-genital atrium 


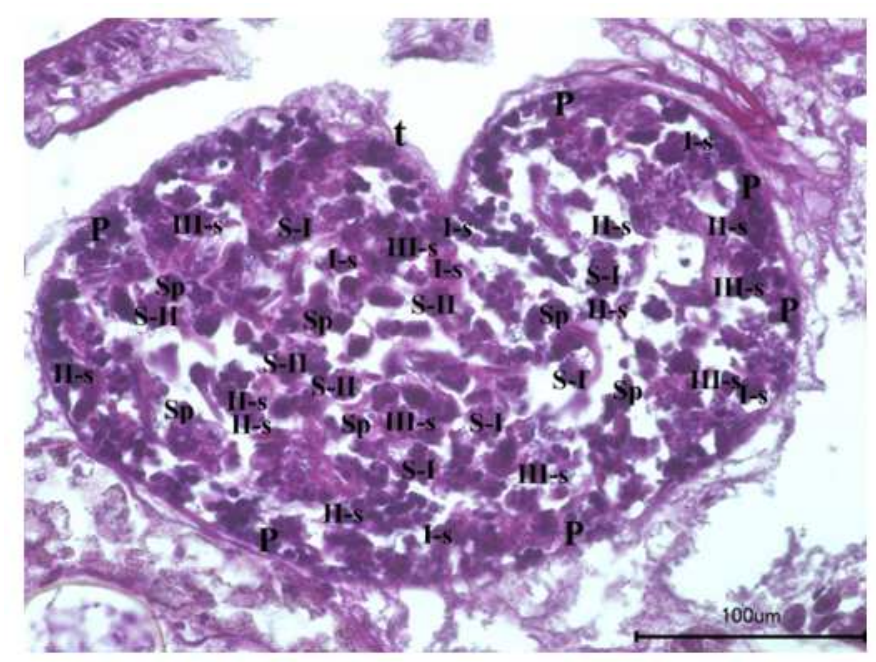

Fig. 2. Testis of Parastrigea robusta; Coloring with hematoxylin-eosin acc. to Erlich. T- teste; P-primordial germ cells; I-s-type Ad Spermatogonia; II-s-type Ap Spermatogonia; III-s-type B Spermatogonia; S-I-primary spermatocytes; S-II-secondary spermatocytes; Sp-spermatids
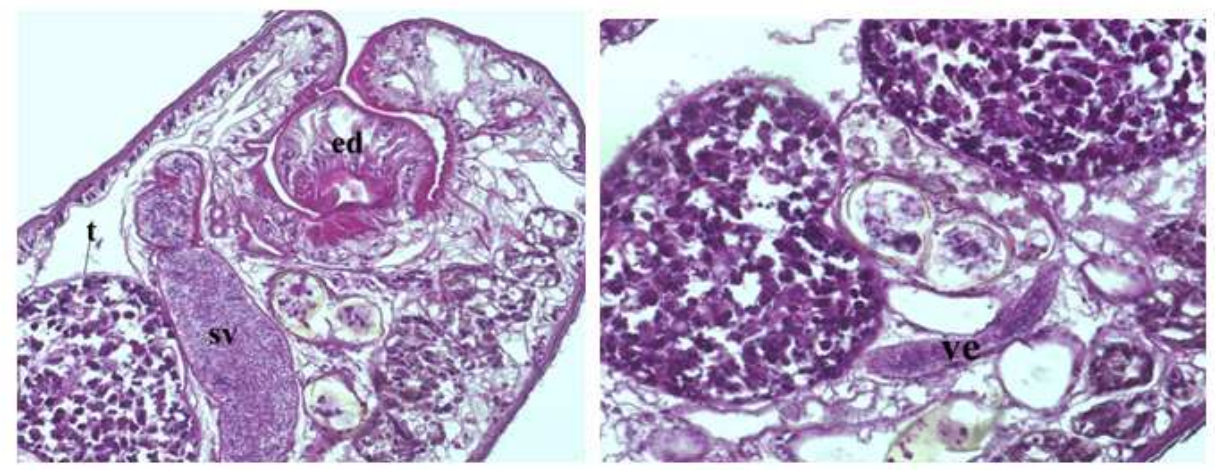

Fig. 3. Male reproductive system in the Parastrigea robusta trematode; Coloring with hematoxylin-eosin acc. to Erlich. T-testes; svseminal vesicle; ed-ejaculatory duct; ve-vasa efferentia

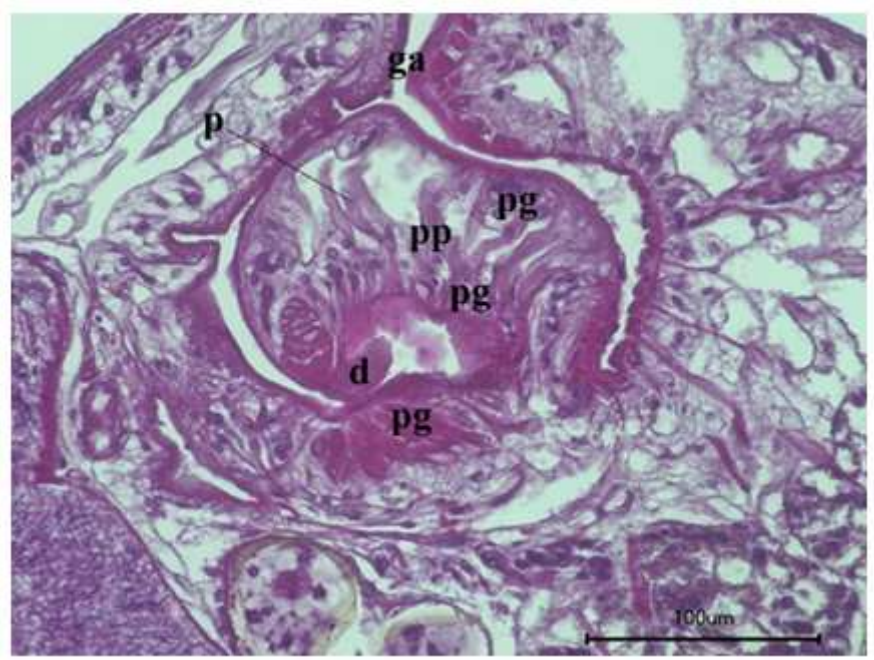

Fig. 4. The distal part of the male reproductive system in the Parastrigea robusta trematode; Coloring with hematoxylin-eosin acc. to Erlich. p-proximal part of the ejaculatory duct; d-distal portion of ejaculatory duct; pg-prostate gland; pp-pars prostatica; ga-genital atrium 
The vasa deferens of Parastrigea robusta significantly expanded and forms a seminal vesicle, consisting of two blades, filled with male germ cells (Fig. 3). The seminal vesicle has two blades; its length is $380 \mu \mathrm{m}$. The seminal vesicle narrows and develops into the ejaculatory duct.

The proximal part of the ejaculatory duct expands into a small elongated cavity, annularly curved in the cavity of genital atrium (Fig. 3 and 4). The distal ejaculatory duct continues into the narrow short duct that opens into the genital atrium (Fig. 4). The length of the proximal area of the ejaculatory duct is $228.6 \mu \mathrm{m}$, its width is 65.7 to $77.1 \mu \mathrm{m}$; the length of the distal part is $42.9 \mu \mathrm{m}$ and its width is $18.6 \mu \mathrm{m}$.

The walls of the excretory ducts are stained pink with hematoxylin-eosin and are represented by the connective tissue fibers in the form of thin membranes.

The genital atrium of Parastrigea robusta is a saccular recess in the wall of the body, where terminal parts of the excretory ducts of the reproductive system are opened. The depth of the genital atrium is 174 to $196 \mu \mathrm{m}$.

The genital bursa and cirrhus are absent. The genital cone is terminal; the hole of the genital atrium is shifted closer to the ventral side.

The prostate gland of trematodes is made of single secretory cells, arranged in several rows around the ejaculatory duct and is separated from the surrounding parenchyma by the connective tissue membrane. Glands of two types open into the excretory ducts of the male reproductive system. The secretion of the gland cells is released into the gap of the ejaculatory duct in the form of bubbles and accumulates therein, forming the pars prostatica of the ejaculatory duct (Fig. 4).

\section{Discussion}

Representatives of the Strigeida order constantly attract attention of the researchers. Firstly, by the fact that these are the highest trematodes, which are characterized by a complex development cycle. Secondly, representatives of this order belong to trematodes with differentiated body (Schulz and Gvozdev, 1970; Ginetsinskaya and Dobrovolsky, 1978; Ginetsinskaya, 1968). The literature contains data about the structure of front part of the body, of the Brandes' organ and of maritas' pseudo-suckers. The structure of their rear, or genital, segment has been fragmentarily studied. It is currently known that members of the Strigeida order, in the process of maritogony, feature very rapid separation of the reproductive part of the body and early ripening of the elements of the reproductive system (Golubeva, 2000).

Parastrigea robusta has a reproductive system that is typical for trematodes, but has some features that have not been previously described for this species of trematodes.

As for most trematodes, the male reproductive system of Parastrigea robusta has two testicles. The peculiarity in the structure of the testes of this species of trematodes is in the fact that they have large blades, rounded shape and a fairly large size, as compared to small body size of 2 to $2.5 \mathrm{~mm}$ in length. Most works devoted to studying testes and spermatogenesis contain fragmentary information and only few of them contain full description of the issue. The process of spermatogenesis was first described by Dingier (1910) on the example of the Dicrocoelium lanceatum trematode. Further study of the testes and spermatogenesis by other authors (Taeleb and Mohammadein, 2013; Ignatyev et al., 2014) actually confirmed correctness of Dingier (1910), but some adjustments and additions have been made. Summarizing the data about peculiarities of spermatogenesis, Reunov (2005) notes that the process of spermatogenesis is highly species-specific. This peculiarity, same as the morphology of male germ cells, is most related to the conditions of fertilization and the peculiarities of reproduction of the animals, rather than to their taxonomic position and species evolution. A representative of the Strigeata suborder, Parastrigea robusta, which we studied, a more orderly arrangement of clones of the primary and secondary spermatocytes is observed; the distance between the division islands is uniform and male germ cells retain the clonal structure until the final stages of male germ cells differentiation. Spermatogenesis in the testes is fast, as evidenced by considerable accumulation of male germ cells along the entire length of the ducts in the male reproductive system; especially significant concentration of male germ cells is observed in the two-blade seminal vesicle. Active work of the testes is associated with the complex life cycle of trematodes (Vojtek, 1972; Odening, 1966) and with elimination at various stages of existence.

Also noteworthy is the specific development of the genital cone that protrudes far from the bottom of the genital atrium like genital papilla. It was Dubois (1938) who noticed in his studies that some Strigeida genera had no genital bursa; a so-called ejaculatory bursa was present instead. Our studies confirm the absence of the genital bursa and the cirrhus. In modern literature on helminthology, the term of ejaculatory bursa is virtually nonexistent, so we tend to call the differentiated part of the ejaculatory duct as a proximal expanded portion and the distal narrowed part of the ejaculatory duct. These terms have already been used by Podvyaznaya (1996) for describing the male reproductive system and the genital atrium of the Allassogonoporus amphoraeformis parasite in bats.

In Parastrigea robusta, glands of two types open into the excretory ducts of the male reproductive system, which is essentially not new to trematodes and has been noted in other species (Guptam et al., 1983; Wittrock, 1986). By the external signs, the types of glandular cells discovered by us differ little from the prostate glands 
described by Wittrock D. for Quinqueserialis quinqueserialis (Wittrock, 1986). Podvyaznaya (1996), studying trematode A. amphoraeformis, has discovered that the secretion of the prostate gland of one type is ejaculated into the cavity of the seminal vesicle and that of the other - into the proximal part of the ejaculatory duct. All prostate glands of flukes with having a cirrhus pouch are enclosed in it. As shown by the study of A. amphoraeformis (Podvyaznaya, 1996) that is completely free of the genital bursa, the glands that open into the seminal vesicle and ejaculatory duct are located in this specie absolutely separately. Unfortunately, studies at the light-optical level cannot definitely show where the gland ducts open - into the seminal vesicle, or, like in most species, into the proximal part of the ejaculatory duct. We do not exclude the possibility that the ducts of one type of glandular cells of the prostate glands open into the seminal vesicle, since the species of the Parastrigea robusta trematode studied by us does not have a genital bursa and the seminal vesicle, the prostate gland and the ejaculatory duct are located freely in the parenchyma of the body. For studying this issue, a study with an electronic microscope is required.

\section{Conclusion}

Thus, the obtained results have supplemented the data about fine morphology of the organs of the male reproductive system in Parastrigea robusta trematodes with new, previously unknown details.

Testes of Parastrigea robusta have large blades and rounded shape; they are compactly arranged next to each other. The process of spermatogenesis in the testes is quick, since a significant concentration of male germ cells is discovered along the entire length of vasa deferens and in the cavity of the seminal vesicle. Location of clones of primary and secondary spermatocytes is well-ordered; the distance between the division islands is uniform, the male germ cells retain the clonal structure up to the final stages of differentiation of spermatids; the genital bursa and the cirrhus are absent.

The terminal parts of the reproductive system are located in the cavity of the genital atrium and are represented by the proximal (expanded) and distal (narrowed) parts of the ejaculatory duct. The genital cone is terminal; the hole of the genital atrium is shifted closer to the ventral side.

The prostate gland of trematodes is represented by single secretory cells arranged in several rows around the ejaculatory duct and is separated from the surrounding parenchyma by the connective tissue membrane. Unicellular glands of two types open into the excretory ducts of the male reproductive system. In our opinion, the secret of the prostate gland of the first type is ejaculated into the cavity of the seminal vesicle and secretion of the other type of gland cells - into the proximal part of the ejaculatory duct.
We would like to thank the Severtsov Institute of Ecology and Evolution of the Russian Academy of Sciences, on whose base the histological examination was performed, especially to the Head of the Office of Histology and Microscopy, Candidate of Biological Sciences E.D. Pavlov.

\section{Acknowledgement}

We would like to thank all the persons who helped us during our research.

\section{Author's Contributions}

Rimma Meyramovna Ualiyeva: Provided leadership and coordinated the implementation of research work, analyzed and interpreted the study findings, drew conclusions.

Kanat Kombarovich Akhmetov: Conducted research, compiled the literary review, analyzed and interpreted the results.

Indira Bulatovna Altayeva: Involved in all experiments, obtained data analyses and contributed to the scientific writing of the manuscript.

Alexey Vasilyevich Surov: Conducted research, compiled the literary review, interpreted the results obtained and drew conclusions.

\section{Ethics}

This article is original and contains unpublished material. All the authors have read and approved the manuscript and no ethical issues involved.

\section{References}

Terentieva, Z.H. and E.A. Kostevich, 2009. Adaptacija parazitov $\mathrm{v}$ organizme zhivotnyh [Adaptation of Parasites in the Organism of Animals]. J. Orenburg State Agrar. Univ., 22-2: 278-279.

Zhavoronkova, N.V. and A.I. Novak, 2015. Adaptacii parazitov $\mathrm{k}$ realizacii biologicheskogo cikla $\mathrm{v}$ razlichnyh jekologicheskih uslovijah [Adaptation of parasites to implementation of the biological cycle in different ecological conditions]. Theory Pract. Parasitic Dis. Anim., 16: 162-164.

Kurochkin, Y.V., 1990. Prikladnye i nauchnye aspekty morskoj parazitologii. Biologicheskie osnovy rybovodstva: Parazity i bolezni ryb [Applied and scientific aspects of marine parasitology. Biological Bases of Fishery: Parasites and diseases in fish]. 1st Edn., Nauka, Moscow.

Kiseli, D., 1962. Prakticheskaja mikrotehnika i gistohimija [Practical Microtechnology and Histochemistry]. 1st Edn., Publishing House of AS of Hungary, Budapest, pp: 399. 
Tacahiro, F., J. Yoichi and M. Takayuki, 1977. Ultrastructural observation of the spermatozoon and spermatogenesis. Japanese J. Parasitol., 26: 32-42.

Schulz, R.S. and E.V. Gvozdev, 1970. Osnovy obshhej gel'mintologii. [Fundamentals of general helminthology]. 1st Edn., Science. Moscow.

Ginetsinskaya, T.A. and A.A. Dobrovolsky, 1978. Chastnaja parazitologija. [Private Parasitology]. 1st Edn., Vysshaya Shkola, Moscow, pp: 303.

Ginetsinskaya, T.A., 1968. Trematody, ih zhiznennye cikly, biologija i jevoljucija [Trematodes, Their Life Cycles, Biology and Evolution]. 1st Edn., Nauka, Leningrad, pp: 410.

Golubeva, E.B., 2000. Razvitie polovoj sistemy Ichthyocotylurus variegatus (Trematoda: Strigeidae) [Development of eproductive system in ichthyocotylurus variegatus (Trematoda: Strigeidae)]. Parasitology, 34: 100-110.

Dingier, M., 1910. Uber die Spermatogenese des Dicrocoelium lanceatum Still Hass et. Arch. Zellforsch.

Taeleb, A.A. and A.M. Mohammadein, 2013. Description of spermatogenesis and sperm ultrastructure of acanthostomum (Atrophocaecum) aswaninesis wannas, 1977 (Digenea, Acanthostomatidae), a Parasite of Bagrus Bayad in Egyp. J. Basic Applied Zool., 66: 47-59.

Ignatyev, G.A., I.I. Rakhimov and N.V. Salakhov, 2014. Formirovanie nedifferencirovannyh spermatogonij fasciola hepatica [Formation of undifferentiated spermatogonia in fasciola hepatica] (Linnaeus, 1758). Scientific Notes Kazan Bauman State Acad. Vet. Med., 2: 90-93.

Reunov, A.A., 2005. Spermatogenez mnogokletochnyh zhivotnyh [Spermatogenesis in Multicellular Animals]. 1st Edn., Nauka, Moscow, pp: 123.
Vojtek, J., 1972. Observations on the life cycle of Parastrigea robusta Szidat, 1928 (Trematoda: Strigeidae) in Czechoslovakia. Folia Parasitol., 19: 210-210. PMID: 4545812

Odening, K., 1966. Life cycles of the duck trematodes parastrigea robusta and catatropis verrucosa in the berlin region. Monatsh Veterinarmed, 21 : 663-667. PMID: 6009278

Dubois, G., 1938. Monographie des strigeida (Trematoda). 1st Edn., Société Neuchâteloise Des Sciences Naturelles, Neuchâtel, pp : 535.

Podvyaznaya, I.M., 1996. Tonkoe stroenie muzhskoj polovoj sistemy i genitalnogo atriuma parazita letuchih myshej Allassogonoporus amphoraeformis (Trematoda: Allassogonoporidae) [Fine structure of the male reproductive system and the genital atrium in bat parasite allassogonoporus amphoraeformis (Trematoda: Allassogonoporidae)]. Parasitology, 3: 229-235.

Guptam, B.C., S.S. Guraya and V.R. Parshad, 1983. Morphological and histochemical studies on the prostate gland of developing and adult paramphistomum cervi (Digenea: paramphistomatidae). Int. J. Invertebiol. Reproduct., 6: 219-228. DOI: 10.1080/01651269.1983.10510046

Wittrock, D.D., 1986. Histochemical and ultrastructural studies of the prostate gland of quinqueserialis quinqueserialis (Trematoda: Notocotylidae). Trans. Am. Microscopical Society, 105: 365-375. DOI: $10.2307 / 3226523$ 